\title{
Assembly and Testing of a Tritium and lodine Removal System for Use with Advanced Tritium Pretreatment
}

Nuclear Technology

Research and Development

Approved for public release. Distribution is unlimited

Prepared for U.S. Department of Energy Material Recovery and Waste Form Development Campaign R. T. Jubin, S. H. Bruffey, J. A. Jordan, G. D. DelCul

Oak Ridge National Laboratory 19 September 2017 NTRD-MRWFD-2017-000157 ORNL/TM-2017/464 



\section{DISCLAIMER}

This information was prepared as an account of work sponsored by an agency of the U.S. Government. Neither the U.S. Government nor any agency thereof, nor any of their employees, makes any warranty, expressed or implied, or assumes any legal liability or responsibility for the accuracy, completeness, or usefulness, of any information, apparatus, product, or process disclosed, or represents that its use would not infringe privately owned rights. References herein to any specific commercial product, process, or service by trade name, trade mark, manufacturer, or otherwise, does not necessarily constitute or imply its endorsement, recommendation, or favoring by the U.S. Government or any agency thereof. The views and opinions of authors expressed herein do not necessarily state or reflect those of the U.S. Government or any agency thereof. 



\section{SUMMARY}

US regulations will require the removal of iodine and tritium, along with other volatile and semivolatile radionuclides, from the off-gas streams of nuclear fuel reprocessing plants. Tritium pretreatment is a head-end operation that could be incorporated within nuclear fuel reprocessing plants for the upfront removal and trapping of these volatiles species. Quantitative, up-front removal in a single compact system is of significant advantage because otherwise tritium and iodine distributes to other unit operations, each of which have associated off-gas streams also requiring treatment.

Oak Ridge National Laboratory is presently developing an advanced tritium pretreatment process based on the oxidation of used nuclear fuel at low temperature using $\mathrm{NO}_{2} / \mathrm{O}_{2}$ mixtures, which produces a fine powder. This process can result in the quantitative volatilization of both tritium and iodine. The powder product can be selected to be $\mathrm{U}_{3} \mathrm{O}_{8}, \mathrm{UO}_{3}$, or a nitrate by adjusting the processing conditions and the process can be readily interfaced to either conventional aqueous-based or advanced pyrochemical-based reprocessing plants.

In preparation for a planned kilogram-scale hot cell demonstration of the advanced tritium pretreatment process with used nuclear fuel (UNF), an integrated iodine and tritium capture system was designed and assembled. Three experimental runs of this system were completed successfully. All the samples were submitted for analysis. The results and data analysis will be covered in a subsequent report to be issued by the Off-Gas Sigma Team. Several additional tests should be undertaken to provide additional information on the system's performance. The objectives for the additional tests and test conditions are presented in this report. 
This page is intentionally left blank. 


\section{CONTENTS}

SUMMARY

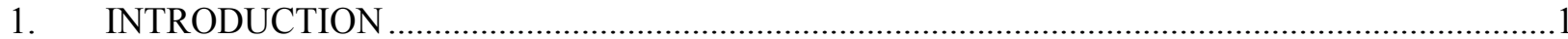

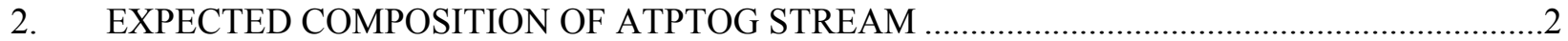

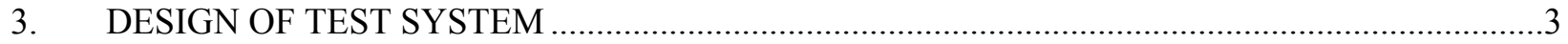

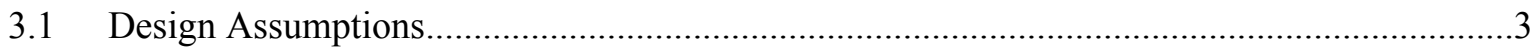

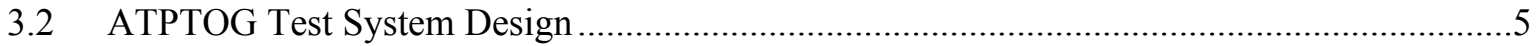

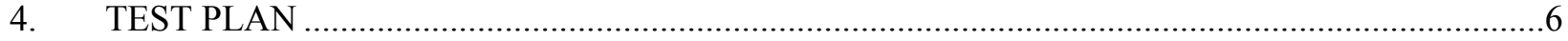

4.1 General Operation of the ATPTOG Treatment Test Loop .................................................6

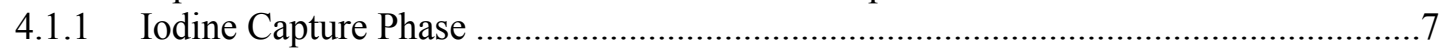

4.1.2 System Purge and Tritium Bed Regeneration.......................................................

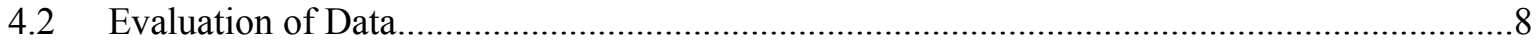

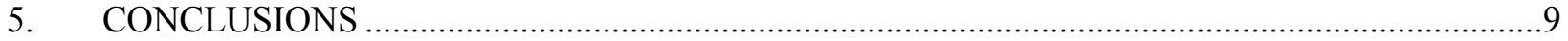

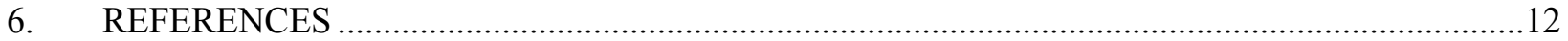


This page is intentionally left blank. 


\section{FIGURES}

Figure 1: Flowsheet for $\mathrm{NO}_{2}$ treatment at ORNL's Building 3525 (Johnson and DelCul 2016).

Figure 2: Schematic of a closed-loop recirculation system for the industrial pretreatment of light water reactor used fuel to remove tritium and iodine.

Figure 3: Flowsheet for the ATPTOG treatment test system. ...........................................................6

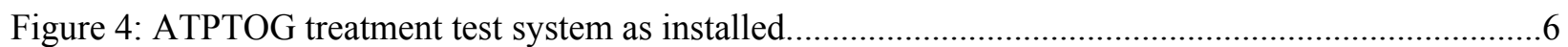

\section{TABLES}

Table 1: Estimation of gas volume for ATPT demonstration system......................................................

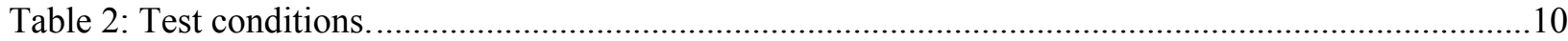

Table 3: Additional test conditions for future evaluation of system performance. ................................11 
This page is intentionally left blank. 
Assembly and Testing of a Tritium and lodine Removal System for Use with Advanced Tritium Pretreatment

\section{ACRONYMS}

3AMS 3A molecular sieve

ATPT advanced tritium pretreatment

ATPTOG advanced tritium pretreatment off-gas

ORNL Oak Ridge National Laboratory

TPT tritium pretreatment

UNF used nuclear fuel 
This page is intentionally left blank. 


\section{DESIGN OF A TRITIUM AND IODINE REMOVAL SYSTEM FOR USE WITH ADVANCED TRITIUM PRETREATMENT}

\section{INTRODUCTION}

US regulations will require the removal of iodine and tritium, along with other volatile and semivolatile radionuclides, from the off-gas streams of nuclear fuel reprocessing plants. In traditional aqueous reprocessing of used nuclear fuel (UNF), the volatile fission products are released during the acid dissolution step. Although several of these such as carbon $\left(\right.$ as $\left.\mathrm{CO}_{2}\right)$, krypton, and iodine are released into the off-gas stream, the bulk of the tritium is converted to water to become part of the water circulating within the plant. Once the tritium is introduced into the aqueous portion of the reprocessing plant, the tritiated water can be separated from the plant water only by an isotopic separation technique. In the absence of a large isotopic separation process to recover the tritium, management of the tritium releases from the reprocessing plant requires either (1) the capture of large quantities of water from the off-gas streams (where the concentration of tritiated water is very small) or (2) the removal and replacement of large quantities of recycled water and acid from the plant (Jubin and Spencer 2017). As an alternative to these processes, tritium pretreatment was devised to separate and recover the tritium in a dry process with a separate, low volume off-gas stream before the fuel reached the aqueous dissolution step, avoiding its migration to other unit operations and other off-gas streams.

Traditional dry tritium pretreatment (TPT) oxidizes the $\mathrm{UO}_{2}$-based UNF with oxygen, usually in concentrations ranging from that in ordinary air to pure oxygen. In dry TPT, the $\mathrm{UO}_{2}$ is converted to $\mathrm{U}_{3} \mathrm{O}_{8}$, quantitatively releasing the tritium and converting it to water vapor, which may then be removed from the process off-gas with solid molecular sieve sorbents. Traditional TPT is conducted at high temperatures $\left(600^{\circ} \mathrm{C}\right)$ and can take an extended period of time $(4-12 \mathrm{~h})$ to achieve full fuel oxidation.

Advanced TPT (ATPT) is a variation on air TPT and uses nitrogen dioxide $\left(\mathrm{NO}_{2}\right)$ as the oxidant. It results in the quantitative volatilization of tritium and potentially the quantitative volatilization of iodine. The powder product can be selected to be $\mathrm{U}_{3} \mathrm{O}_{8}, \mathrm{UO}_{3}$, or a nitrated form of uranium by adjusting the processing conditions. Regardless of conditions, the process can be readily integrated into either conventional aqueous-based or advanced pyrochemical-based reprocessing plants. Use of $\mathrm{NO}_{2}$ introduces different challenges to the recovery of the tritium from the off-gas compared to the challenges of recovering tritium from traditional TPT.

Up-front removal of iodine by ATPT is of significant advantage because otherwise it distributes to several unit operations and their associated off-gas streams. The ATPT process displays improved oxidation kinetics at lower temperatures relative to TPT, which reduces the heat-up time and the space-time of the material in the reactor, both of which ultimately reduce the size of the processing equipment.

ATPT is currently under development at Oak Ridge National Laboratory (ORNL); a kilogram-scale hot cell demonstration with UNF is planned. The overall goal is to develop the process to a technologyreadiness level sufficient to evaluate and estimate the cost of an engineering-scale implementation (DelCul et al. 2012).

The off-gas stream generated by ATPT will contain high levels of $\mathrm{NO}_{2}$ in addition to iodine, tritium, and other volatile and semivolatile radionuclides contained in $\mathrm{UNF}$, including ${ }^{14} \mathrm{CO}_{2},{ }^{85} \mathrm{Kr}$, and Xe. In support of the ATPT hot cell demonstration, off-gas treatment methods for the advanced tritium pretreatment offgas (ATPTOG) to recover tritium and iodine and separate them from one another have been evaluated (Spencer et al. 2017). Based on that analysis, an iodine and tritium capture system has been designed and built that could interface with the laboratory ATPT system but will be tested without the ATPT reactor in 
place. Note that in this initial demonstration there is no requirement to capture the $\mathrm{CO}_{2},{ }^{85} \mathrm{Kr}$, or $\mathrm{Xe}$. The focus of the laboratory test system is to verify component performance before finalizing the design and fabricating the system that will interface with the ATPT reactor for hot cell testing. This report is intended to describe the ATPTOG test system design, interfaces, and the initial series of tests to be performed. The results from these tests will be presented in a subsequent report.

\section{EXPECTED COMPOSITION OF ATPTOG STREAM}

The assessment conducted by Spencer et al., 2017 indicated that the off-gas stream generated by ATPT will contain high levels of $\mathrm{NO}_{2}$ in addition to iodine and tritium, and other volatile and semivolatile radionuclides contained in $\mathrm{UNF}$, including ${ }^{14} \mathrm{CO}_{2},{ }^{85} \mathrm{Kr}$, and Xe. The concentration of the iodine, tritium and other volatile and semivolatile radionuclides may be higher than in standard air TPT due to the recirculation of the oxidizing gas stream. The composition of the ATPTOG is unique among reprocessing operations because of its high $\mathrm{NO}_{2}$ concentration, so performance data for potential tritium sorbents are largely unavailable for applicable conditions.

Results of the stream assessment indicated that iodine was expected at a maximum concentration of $2,700 \mathrm{ppm}$ in the planned hot cell demonstration of the ATPTOG. Online removal of iodine from the ATPT recirculation loop could lower this concentration significantly. Silver-nitrate impregnated alumina (AgA) was identified as a promising sorbent for this application, and preliminary bed sizes were determined.

Tritium is expected within the ATPTOG $\mathrm{kg}$ scale hot cell demonstrations at a maximum concentration of $25-50 \mathrm{ppm}$ and will be found as either tritiated nitric acid (at temperatures below $50^{\circ} \mathrm{C}$ ) or tritiated water (at temperatures above $250^{\circ} \mathrm{C}$ ). Because of the dilute concentration, it was determined that allowing the tritium to build up to the maximum concentration within the ATPT recirculation loop and treating a bleed stream at the conclusion of testing was the most promising approach to effect quantitative tritium removal.

Several materials were identified by Spencer et al., 2017 as potential nitric acid or water sorbents. For nitric acid, removal could be accomplished at relatively low temperatures using sorbents including nylon fibers, silica gel, and 3A molecular sieves (3AMS). For water removal at high temperatures, 3AMS and silica gel were identified as candidate materials. While suitable for nitric acid recovery, nylon fibers were excluded from the scoping tests due to material compatibility issues with the $\mathrm{NO}_{2}$ environment and potential radiolytic degradation in full scale implemenation. Scoping tests were conducted on the 3AMS by exposing the sorbent to a high concentration of $\mathrm{NO}_{2}$ under static conditions for up to 1 month before the subsequent loading of water (Jordan and Jubin 2017). The results of these tests indicated no measureable effect of $\mathrm{NO}_{2}$ aging on the water adsorption capacity of $3 \mathrm{AMS}$. The loading rate of water on 3 AMS decreased slightly on exposure to $\mathrm{NO}_{2}$ before loading.

Similar static aging tests for the AgA iodine sorbent results show that the iodine capture capacity of AgA is reduced by exposure to high concentrations of $\mathrm{NO}_{2}$. The iodine capacity reductions were $16 \%, 36 \%$, and $76 \%$ for 1,2 , and 4 week exposures, respectively. This is less capacity loss than that seen in similar testing with the $\mathrm{Ag}^{0} \mathrm{Z}$ sorbent in which $\sim 90 \%$ capacity was lost after 1 week of exposure (Jubin et al. 2013). It is speculated that the observed higher iodine capacity of the AgA may reflect the form of the silver contained in the sorbent. In the case of $\mathrm{AgZ}$ the silver is a reduced to $\mathrm{Ag}^{0}$ whereas in the $\mathrm{AgA}$, the silver remains as $\mathrm{AgNO}_{3}$ on the surface. 


\section{DESIGN OF TEST SYSTEM}

\subsection{Design Assumptions}

The flowsheet for the ATPT demonstration is shown in Figure 1. There are several differences between this configuration and a flowsheet proposed for use in a larger scale operation, which is presented in Figure 2. In both cases, the ATPT reaction vessel will be contained within a hot cell but for the demonstration in Building 3525 the off-gas traps are expected to be contained in a heated enclosure external to the hot cell, whereas all components used in the larger demonstration would be located within a shielded facility (hot cell or canyon-type). To facilitate off-gas trapping external to the cell in smallerscale testing, route the off-gas out of the cell, HEPA filters will be required that might not be used at larger scale. A trap for semivolatiles (primarily ruthenium) is shown in the recirculation loop for the larger process but will not be included in the small-scale demonstration in which sintered metal HEPA filters will most likely function in this role. In addition, the schematic for the large-scale system shows the recovery of the noble gases that will not be targeted in the demonstration. There is also no condensation and recovery of the $\mathrm{NO}_{2}$ from the bleed stream in the small-scale demonstration as is shown for the larger scale operation.

An oxidation reaction converts the $\mathrm{UO}_{2}$ to $\mathrm{U}_{3} \mathrm{O}_{8}$, reducing the $\mathrm{NO}_{2}$ to $\mathrm{NO}$. Addition of oxygen in the cooler portions of the flow circuit converts the $\mathrm{NO}$ back to $\mathrm{NO}_{2}$. In effect, this permits oxygen to be the primary consumable reagent, with the oxygen reporting to the condensed solid phase $\mathrm{U}_{3} \mathrm{O}_{8}$. Oxygen flow is adjusted to maintain a constant pressure in the system. The volatile fission products released from the fuel represent only a small volume, making containment of the gases within a closed circulation loop practical. This results in fission product gases accumulating to higher concentrations than is possible in systems using flow-through air as the reagent. The treatment system piping is designed to accommodate two modes of operation. In one mode, the process gases are circulated in a closed loop until the fuel is fully treated, and then the gases are routed through the off-gas trapping system. In the other mode, the process gases may circulate through the trapping systems while the fuel is being treated. In the latter mode, an online oxygen sensor located within the heated enclosure may be used to track progress of the reaction. The gas volume of the recirculation loop was estimated to total about $6.5 \mathrm{~L}$, as is shown in Table 1. The gas flow rate is expected to be $2 \mathrm{~L} / \mathrm{min}$. Additional system volume associated with the offgas trapping components (located in the out-of-cell enclosure) will not be estimated in this design effort. 


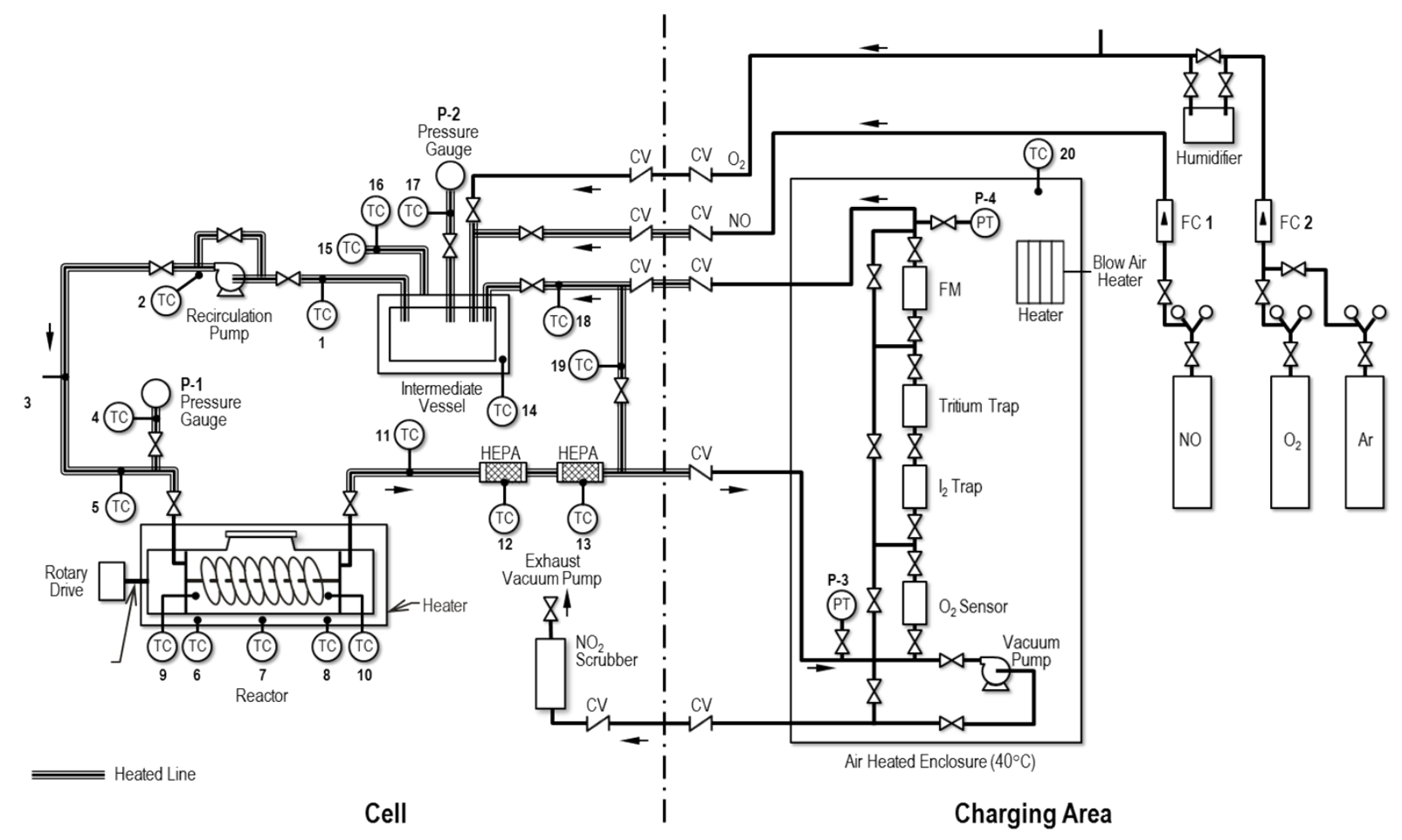

Figure 1: Flowsheet for $\mathrm{NO}_{2}$ treatment at ORNL's Building 3525 (Johnson and DelCul 2016).

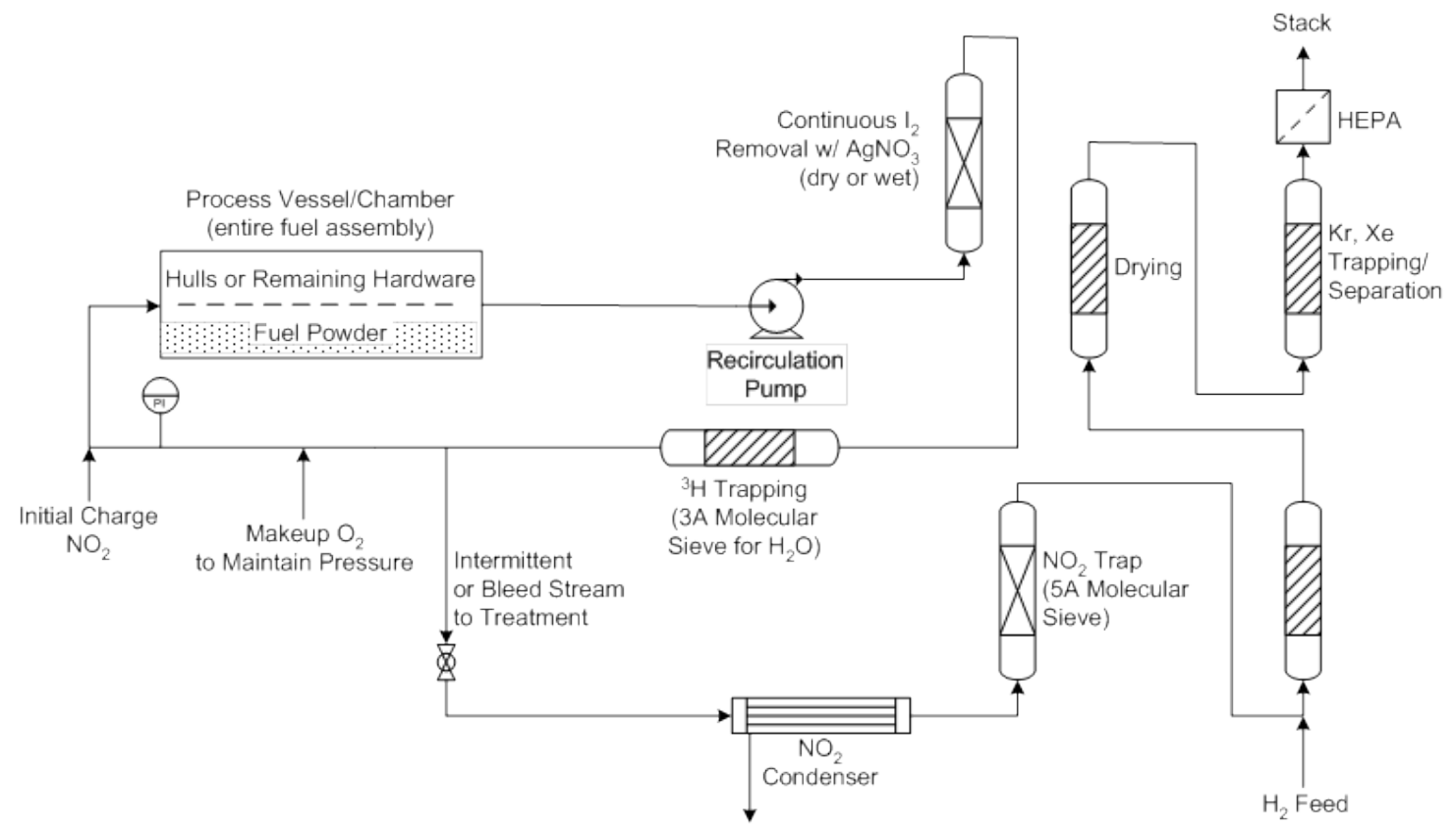

Figure 2: Schematic of a closed-loop recirculation system for the industrial pretreatment of light water reactor used fuel to remove tritium and iodine. 
Table 1: Estimation of gas volume for ATPT demonstration system.

\begin{tabular}{lc}
\hline \multicolumn{1}{c}{$\begin{array}{c}\text { Recirculation loop } \\
\text { components }\end{array}$} & $\begin{array}{c}\text { Volume } \\
\text { (L) }\end{array}$ \\
\hline Reactor & 3.0 \\
$\begin{array}{l}\text { Intermediate vessel or } \\
\text { surge tank }\end{array}$ & 4.6 \\
In-cell connecting tubing & 0.2 \\
Off-gas traps and tubing & 0.2 \\
Total & $\mathbf{7 . 1}$ \\
\hline
\end{tabular}

\subsection{ATPTOG Test System Design}

To evaluate the performance of the iodine and tritium recovery beds under ATPT off-gas conditions prior to the kilogram scale hot cell demonstrations using UNF, a relatively simple experimental trapping system design was utilized. The initial experimental concepts for the iodine and tritium trapping system involved the oxidation of depleted $\mathrm{UO}_{2}$ pellets with the concurrent addition of iodine and tritium to the reactor vessel. (This was an alternative to attempting to produce a UNF simulant containing both iodine and tritium.) It was then decided to simplify the experimental operations by the elimination of the $\mathrm{UO}_{2}$ oxidation as these had been previously demonstrated and directly adding the iodine and tritium to the recirculating $\mathrm{NO}_{\mathrm{x}}$ stream. To further simplify the experimental design and focus on the key aspects of the off-gas system tests, the experimental system did not include the reactor or the $\mathrm{NO}_{\mathrm{x}}$ scrubber that will be used in the hot cell ATPT demonstration

The dilute tritium concentrations expected within the kilogram scale hot cell ATPT loop demonstration led to a decision to remove tritium at the conclusion of testing from a bleed stream. As a result the tritium trap is bypassed until the end of each test to avoid the co-adsorption of iodine while the $\mathrm{NO}_{\mathrm{x}}$ flow is in recirculation mode. Iodine removal will be conducted continuously within the recirculation loop. A schematic depicting this treatment process concept is shown in Figure 3. This is not a detailed process instrumentation diagram and does not show all inlet streams, valves, and associated equipment. Figure 4 shows the test system as installed in the hood in Lab A-17, Building 4500N. 


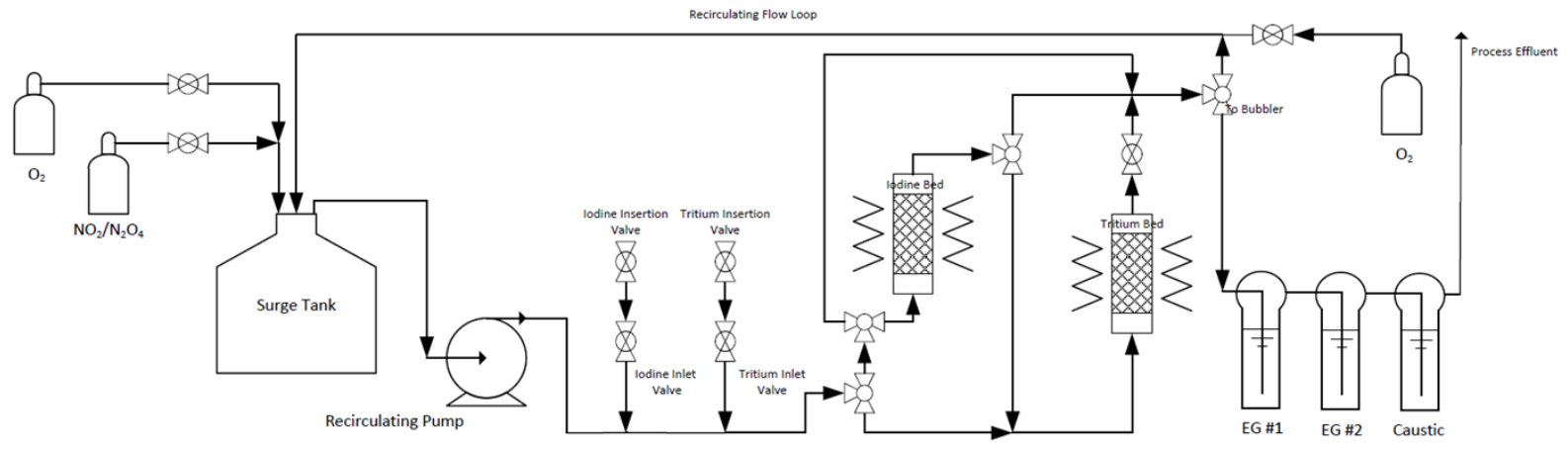

Figure 3: Flowsheet for the ATPTOG treatment test system.

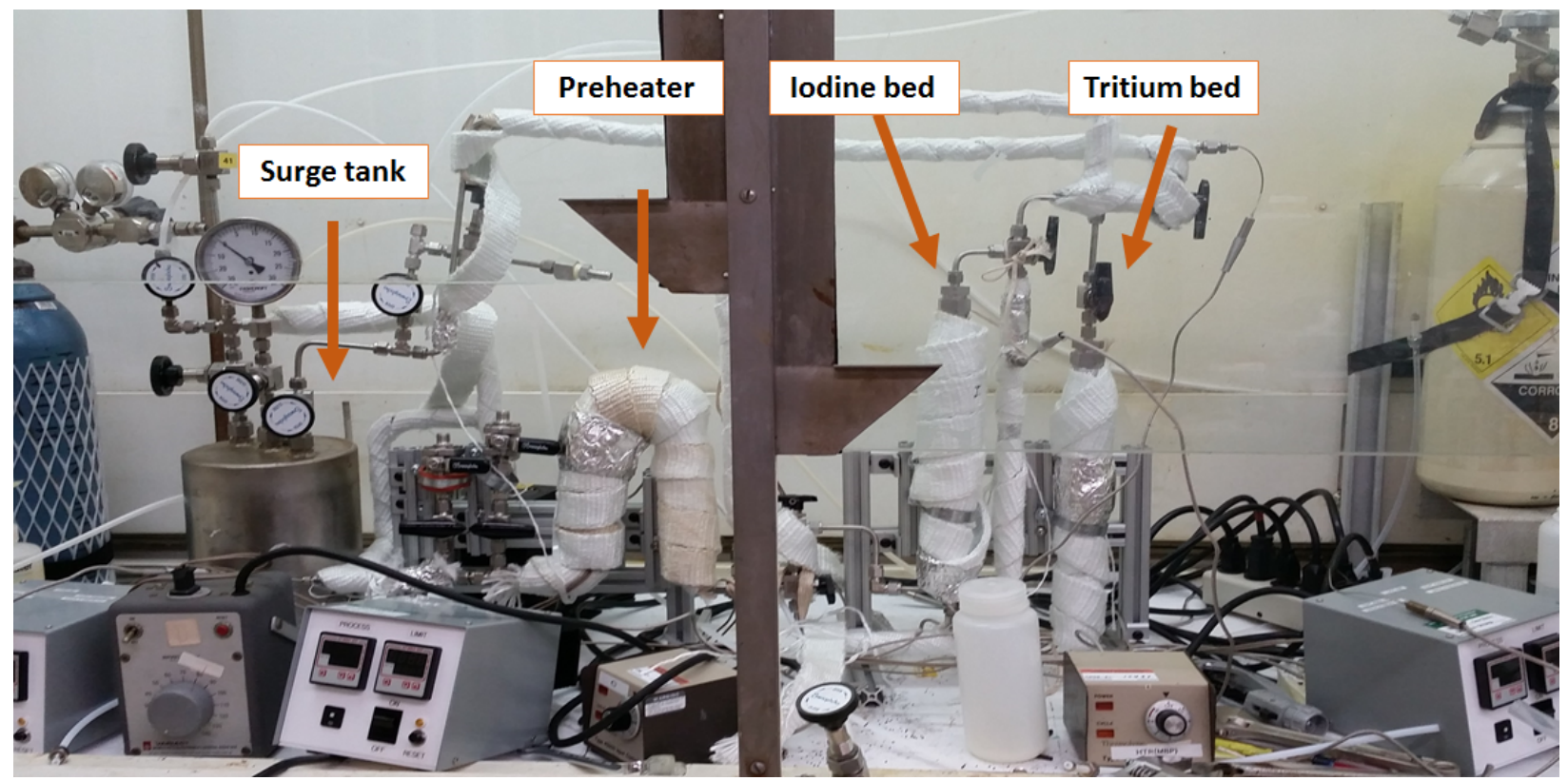

Figure 4: ATPTOG treatment test system as installed.

\section{TEST PLAN}

\subsection{General Operation of the ATPTOG Treatment Test Loop}

This test effort was broken down in to a series of three tests. The conditions for the individual tests are shown in Table 2. Although both high-temperature $\left(90^{\circ} \mathrm{C}\right.$ or $200^{\circ} \mathrm{C}$ depending on the sorbent) and lowtemperature $\left(40^{\circ} \mathrm{C}\right)$ tritium adsorption runs with both tritium adsorbents were initially considered to evaluate the differences in tritium capture efficiency as the equilibrium between water and nitric acid is shifted, it was decided to limit testing to the low-temperature adsorption. In the Building 3525 hot cell configuration, it seemed likely that it would be difficult to maintain the gas at an elevated temperature as it passed through the cell wall to reach the gas traps. This, coupled with the expected low tritiated water 
capacity of the sorbents at the elevated temperatures, were the leading technical reasons to not include the high-temperature effects in the initial set of tests.

Each individual test was conducted using amounts of tritium and iodine that would be present in $500 \mathrm{~g}$ of $55 \mathrm{GW} /$ day, 5-year cooled fuel. Specific details can be found in Spencer et al. (2017). The total water amount corresponds to the amount of all hydrogen isotopes present in $500 \mathrm{~g}$ of fuel. The ${ }^{3} \mathrm{H}$ to ${ }^{2} \mathrm{H}$ and ${ }^{1} \mathrm{H}$ ratios used in testing are lower than would be expected in the actual releases from UNF because the ${ }^{3} \mathrm{H}$ is only used as a tracer for total hydrogen. The total tritium activity within the system was expected to be $0.1 \mathrm{mCi}$ per test. The iodine was delivered to the system as iodine crystals in the amount expected to be present in $500 \mathrm{~g}$ fuel.

\subsection{1 lodine Capture Phase}

The entire test system is a recirculating loop, containing a high $\mathrm{NO}_{2}$ concentration gas mixture with the balance being $\mathrm{O}_{2}$. The system normally operates so that the tritium trap is bypassed. The tritium trap is used only during a final discharge of gas from the system following the simulated gas recycle that would occur during the ATPT process. At this point in the ATPT process, the tritium in the gas phase is at maximum concentration.

Before the start of each run, the iodine column was loaded with silver-nitrate impregnated alumina prepared at ORNL. For tests containing iodine, the column was separated into discrete segments with layers of quartz wool separating the segments. The active length of the iodine bed depth is $10 \mathrm{~cm}$. The iodine bed was operated at $150^{\circ} \mathrm{C}$.

The system valving was set so that a flow loop was established from the recirculation pump to the iodine trap, surge tank and back to the recirculation pump. Nitrogen dioxide and oxygen gas were then introduced into the system to adjust the gas to an approximate $75 \% \mathrm{NO}_{2} / 25 \% \mathrm{O}_{2}$ mixture. After the $\mathrm{NO}_{2}$ and $\mathrm{O}_{2}$ addition to the surge tank, the recirculation pump was started, and the gas stream was heated to $300^{\circ} \mathrm{C}$ to mimic the ATPT process conditions. After the system reaches operating temperature, the tritiated water mixture was introduced into the system through a set of block valves into a heated portion of the off-gas line between the surge tank and the iodine trap.

Because these tests were designed to determine if the sorbents will retain their functionality in an ATPT environment and to what extent will they recovery all of the targeted species, the timing of the introduction of tritium introduction was at the beginning of the run to represent an early release from the fuel and expose the iodine bed to tritium for the longest possible time interval. It was expected that the UNF oxidation process would release iodine at some rate, but the timing and rate is currently unknown. It was also expected that the exposure of the $\mathrm{AgA}$ to the flowing $\mathrm{NO}_{2}$ stream will have some deleterious effect and, as such, a conservative approach and evaluation of the iodine recovery on the slightly aged sorbent was desired. Thus, the iodine introduction took place approximately $2.5 \mathrm{~h}$ into the $4 \mathrm{~h}$ run to allow some $\mathrm{NO}_{2}$ aging to occur. In a similar manner to the tritium, iodine was introduced into the system through a set of block valves into a heated portion of the off-gas line between the surge tank and the iodine trap. The iodine sublimed into the $\mathrm{NO}_{2} / \mathrm{O}_{2}$ gas stream. .

\subsubsection{System Purge and Tritium Bed Regeneration}

At the conclusion of each test, a three-step purge operation was completed. The initial step was to purge the system of $\mathrm{NO}_{2}$ and to capture the tritium from the recirculation gas. The second step recovered captured the tritium from the tritium trap. The third step was to purge the iodine bed of any physisorbed iodine and tritium. Each step will be discussed below.

\subsubsection{Tritium Capture}

After the $\mathrm{NO}_{2} / \mathrm{O}_{2}$ /iodine/tritium gas mixture had circulated through the iodine bed for the specified duration simulating the operational period of the ATPT process, the recirculation pump was turned off, 
and the iodine capture bed was isolated. The system was maintained at normal operating temperatures. The valving was then set to route the gas mixture through the tritium trap. The tritium column contains 612 mesh silica gel or $3 \mathrm{AMS}$ and has a bed depth of $10 \mathrm{~cm}$. The tritium bed was maintained at $40^{\circ} \mathrm{C}$. On exiting the tritium column, the effluent passed through two ethylene glycol bubblers with a final $0.1 \mathrm{M}$ $\mathrm{NaOH}$ bubbler to capture any residual iodine. After loading, the inlet valve to the tritium capture bed was closed and the surge tank vessel was charged with $\mathrm{O}_{2}$ to a pressure of $30 \mathrm{psig}$. Once the system was pressurized, the $\mathrm{O}_{2}$ supply was valved out, and the inlet valve to the tritium capture trap was partially opened to slowly relieve the gas through the tritium trap and bubblers. This pressurization/depressurization process was repeated five times, which was calculated to reduce the concentration of $\mathrm{NO}_{2}$ and tritium to $\sim 0.4 \%$ of the initial values. The ethylene glycol and $\mathrm{NaOH}$ solutions will be analyzed for tritium and iodine.

\subsubsection{Tritium Bed Regeneration}

After the system was discharged fully and purged with $\mathrm{O}_{2}$, the ethylene glycol and caustic solutions were replaced with fresh liquids. The recovered solutions will be analyzed for tritium and iodine. The tritium bed was desorbed with dry $\mathrm{O}_{2}$ gas at a gas rate of $0.5-1.0 \mathrm{~L} / \mathrm{min}$ for $2 \mathrm{~h}$. The regeneration temperature was $90^{\circ} \mathrm{C}$ for silica gel, $250^{\circ} \mathrm{C}$ for the $3 \mathrm{AMS}$, and $120^{\circ} \mathrm{C}$ for the tests not containing a tritium sorbent to prevent any possible condensation in the tritium column. In addition, the effluent from the tritium capture bed was passed through a series of two ethylene glycol bubblers and a caustic bubbler. Upon completion of the purge the recovered solutions will be analyzed for tritium and iodine. At the conclusion of the tritium bed regeneration step, the tritium bed was isolated from the system by closing the inlet and outlet valves. After the iodine bed purge, discussed below, was completed, the sorbent was recovered from the column and will be analyzed for any residual tritium.

\subsubsection{3 lodine Bed Purge}

The system was reconfigured to purge the iodine bed of any physisorbed iodine and tritium. The purge stream from the iodine capture bed was routed through a single ethylene glycol bubbler followed by a $0.1 \mathrm{M} \mathrm{NaOH}$ bubbler. The valves were set to route the purge gas directly through the iodine bed to the bubblers. The iodine capture bed was purged with dry $\mathrm{O}_{2}$ gas at a gas rate of $0.5-1.0 \mathrm{~L} / \mathrm{min}$ for $2 \mathrm{~h}$. The temperature of the bed was maintained at $150^{\circ} \mathrm{C}$. After the system was purged, the ethylene glycol and caustic solutions were recovered and analyzed for tritium and iodine. At the conclusion of the purge step, the iodine capture bed was isolated from the system by closing the inlet and outlet valves. Then the sorbent was recovered from the column and will be analyzed for iodine by neutron activation analysis and for residual tritium by direct liquid scintillation counting to assess the effectiveness of the in-line iodine recovery and to determine the extent of tritium remaining on the bed.

\subsection{Evaluation of Data}

The data on the iodine bed segments will be used to determine the extent of penetration of iodine into the bed (iodine loading data from runs ATPTOG-2 and ATPTOG-3). In addition, the closure of the iodine mass balance will provide confirmation of the ability of ATPT to quantitatively remove the iodine, potentially simplifying the remainder of a plant's off-gas treatment system.

The recovered tritium, along with the tritium contained on the iodine bed, and any residual tritium on the tritium bed will be used to assess the overall effectiveness of the planned tritium accumulation and periodic tritium purge.

Comparison of ethylene glycol activity when tritium sorbent is present (ATPTOG-2 and ATPTOG-3) with the activity recovered by purging directly to the bubblers (ATPTOG-1 and ATPTOG-6) will provide further confirmation of the residual amount of tritium adsorbed on the sorbent bed that could not be desorbed. 


\section{CONCLUSIONS}

The three runs described in this report were successfully completed on September 18, 2017. All the samples have been submitted for analysis. The analysis results and data analysis will be covered in a subsequent report to be issued by the Off-Gas Sigma Team.

Further tests should be undertaken to provide additional information on the system's performance (see Table 3). In the proposed mode of operation, the iodine adsorption bed and the tritium adsorption bed are independent. As a result, data on two separate aspects can be obtained in a single run. These additional runs will allow any adverse effects on the iodine adsorption beds caused by exposure to $\mathrm{NO}_{\mathrm{x}}$ to be evaluated, as well as any effects of higher temperature tritium adsorption.

The data for the iodine bed will be used to determine the extent of penetration of iodine into the bed and to evaluate if there is any measurable degradation (compare iodine loading data from ATPTOG-2 and ATPTOG-3 with ATPTOG-4 and ATPTOG-5) of the sorbent during these relatively short tests.

Comparison of the amount of tritium recovered on the sorbent at low temperature (ATPTOG-2 and ATPTOG-3) versus that at high temperature (ATPTOG-4 and ATPTOG-5) will explore the shifting of the tritium between water and nitric acid species and the relative effectiveness of the two candidate sorbents.

A second configuration of the system would place the tritium adsorption bed in the recirculation line. This should result in lower overall tritium concentrations in the recirculation loop. The tritium recovery efficiency for this mode of operation (ATPTOG-7 and ATPTOG-8) would be compared with that of ATPTOG-2 through ATPTOG-5. The extent of tritium co-adsorption on the iodine trap would be obtained.

Runs ATPTOG-6, ATPTOG-9, and ATPTOG-10 coupled with run ATPTOG-1 will provide data on the closure of the tritium material balance with and without the iodine sorbent bed in place. 
Table 2: Test conditions.

\begin{tabular}{|c|c|c|c|c|c|c|c|}
\hline Run ID & $\begin{array}{l}\text { Iodine } \\
\text { sorbent }\end{array}$ & $\begin{array}{l}\text { Tritium } \\
\text { sorbent }\end{array}$ & $\begin{array}{c}\text { Tritium } \\
\text { sorbent } \\
\text { operating } \\
\text { temperature } \\
\left({ }^{\circ} \mathrm{C}\right) \\
\end{array}$ & $\begin{array}{c}\text { Iodine } \\
\text { introduction }\end{array}$ & $\begin{array}{c}\text { Tritium } \\
\text { introduction }\end{array}$ & $\begin{array}{l}\text { Tritium bed } \\
\text { desorption } \\
\text { temperature } \\
\left({ }^{\circ} \mathrm{C}\right)\end{array}$ & Notes \\
\hline ATPTOG-1 & $\mathrm{AgA}$ & None & $\mathrm{N} / \mathrm{A}$ & None & Initial & N/A & $\begin{array}{l}\text { Establish } \\
\text { tritium/ethylene } \\
\text { glycol baseline } \\
\text { (final NaOH } \\
\text { trap omitted) }\end{array}$ \\
\hline ATPTOG-2 & $\mathrm{AgA}$ & Silica gel & $40^{\circ} \mathrm{C}$ & Mid-run & Initial & $90^{\circ} \mathrm{C}$ & \\
\hline ATPTOG-3 & $\mathrm{AgA}$ & 3A-MS & $40^{\circ} \mathrm{C}$ & Mid-run & Initial & $250^{\circ} \mathrm{C}$ & \\
\hline
\end{tabular}


Table 3: Additional test conditions for future evaluation of system performance.

\begin{tabular}{|c|c|c|c|c|c|c|c|}
\hline Run ID & $\begin{array}{c}\text { Iodine } \\
\text { sorbent }\end{array}$ & $\begin{array}{l}\text { Tritium } \\
\text { sorbent }\end{array}$ & $\begin{array}{c}\text { Tritium } \\
\text { sorbent } \\
\text { operating } \\
\text { temperature } \\
\left({ }^{\circ} \mathrm{C}\right)\end{array}$ & $\begin{array}{c}\text { Iodine } \\
\text { introduction }\end{array}$ & $\begin{array}{c}\text { Tritium } \\
\text { introduction }\end{array}$ & $\begin{array}{c}\text { Tritium bed } \\
\text { desorption } \\
\text { temperature } \\
\left({ }^{\circ} \mathrm{C}\right)\end{array}$ & Notes \\
\hline ATPTOG-4 & $\mathrm{AgA}$ & Silica gel & $55^{\circ} \mathrm{C}$ & Initial & Initial & $90^{\circ} \mathrm{C}$ & \\
\hline ATPTOG-5 & $\mathrm{AgA}$ & 3A-MS & $200^{\circ} \mathrm{C}$ & Initial & Initial & $250^{\circ} \mathrm{C}$ & \\
\hline ATPTOG-6 & $\mathrm{AgA}$ & None & $\mathrm{N} / \mathrm{A}$ & None & Initial & $\mathrm{N} / \mathrm{A}$ & $\begin{array}{l}\text { Confirm } \\
\text { tritium/ethylene } \\
\text { glycol baseline }\end{array}$ \\
\hline ATPTOG-7 & $\mathrm{AgA}$ & Silica gel & $55^{\circ} \mathrm{C}$ & Mid-run & Initial & $90^{\circ} \mathrm{C}$ & $\begin{array}{l}\text { Both tritium } \\
\text { and iodine traps } \\
\text { in recirculation } \\
\text { loop }\end{array}$ \\
\hline ATPTOG-8 & $\mathrm{AgA}$ & 3A-MS & $200^{\circ} \mathrm{C}$ & Mid-run & Initial & $250^{\circ} \mathrm{C}$ & $\begin{array}{l}\text { Both tritium } \\
\text { and iodine traps } \\
\text { in recirculation } \\
\text { loop }\end{array}$ \\
\hline ATPTOG-9 & None & None & N/A & None & Initial & N/A & $\begin{array}{l}\text { Confirm } \\
\text { tritium/ethylene } \\
\text { glycol baseline }\end{array}$ \\
\hline ATPTOG-10 & None & None & $\mathrm{N} / \mathrm{A}$ & None & Initial & $\mathrm{N} / \mathrm{A}$ & $\begin{array}{l}\text { Bypass empty } \\
\text { tritium and } \\
\text { iodine columns }\end{array}$ \\
\hline
\end{tabular}




\section{REFERENCES}

DelCul, G. D., Spencer, B. B., Johnson J. A., Collins E. D., and Hunt R. D. "Roadmap for Development of a Dry Head-End Process Using Nitrogen Dioxide," ORNL/TM-2012/600, FCRD-SWF-2013-000069, Oak Ridge National Laboratory, Oak Ridge, TN, Dec. 2012.

Johnson, J. A., and G. D. DelCul. "Reaction System Design for $\mathrm{NO}_{2}$ Oxidation of Used Nuclear Fuel for the FY17 Hot Test." ORNL/LTR-2016/355, Oak Ridge National Laboratory, Oak Ridge, TN. 2016.

Jordan, J. A., and R. T. Jubin, "Stability of Tritium and Iodine Sorbents under Tritium-pretreatment Offgas Conditions," NTRD-MRWFD-2017-000411, ORNL/SR-2017-162, March 31, 2017.

Jubin, R. T., et al. "Iodine Capture Performance of Silver Exchanged Mordenite Exposed to High Levels of $\mathrm{NO}_{2}$." ORNL/LTR-2013/382. Oak Ridge National Laboratory, Oak Ridge, TN. 2013.

Jubin, R. T., and B. B. Spencer, "Evaluation of Tritium Management Approaches on Tritium Waste Volumes in Reprocessing Plants," NTRD-MRWFD-2017-000267, ORNL/TM-2017-307, June 30, 2017.

Spencer, B. B.; Bruffey, S. H.; Jordan, J. A., and Jubin, R. T. "Design of a Tritium and Iodine Removal System for Use with Advanced Tritium Pretreatment." ORNL/SR-2017/116, also NTRD-MRWFD-2017000311, Oak Ridge National Laboratory, Oak Ridge, TN. 2017. 